\begin{tabular}{|c|c|c|c|c|c|c|}
\hline \multirow{4}{*}{ Impact Factor: } & ISRA (India) & $=3.117$ & SIS (USA) & $=0.912$ & ICV (Poland) & $=6.630$ \\
\hline & ISI (Dubai, UAE & $=0.829$ & РИНЦ (Russia) & $=0.156$ & PIF (India) & $=1.940$ \\
\hline & GIF (Australia) & $=0.564$ & ESJI $(\mathrm{KZ})$ & $=8.716$ & IBI (India) & $=4.260$ \\
\hline & JIF & $=1.500$ & SJIF (Morocco) & $=5.667$ & OAJI (USA) & $=0.350$ \\
\hline
\end{tabular}

SOI: $1.1 /$ TAS
International Scientific Journal
Theoretical \& Applied Science
$\begin{array}{ll}\text { p-ISSN: } 2308-4944 \text { (print) } & \text { e-ISSN: } 2409-0085 \text { (online) } \\ \text { Year: } 2019 \quad \text { Issue: } 05 \quad \text { Volume: } 73 \\ \text { Published: } 30.05 .2019 \quad \text { http://T-Science.org }\end{array}$

SECTION 13. Geography. History. Oceanology. Meteorology.
QR - Issue

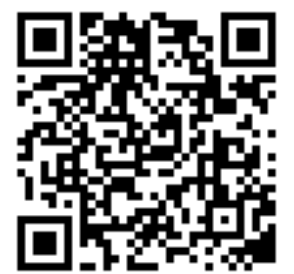

QR - Article

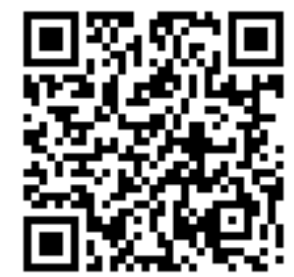

A.A. Biykuziev

Senior lecturer,

National University of Uzbekistan, Tashkent, Republic of Uzbekistan

\title{
POLITICAL AND ECONOMIC INFLUENCE OF THE KANGUY CONFEDERATION ON THE TERRITORY OF THE CENTRAL ASIAN INTERFLUVE
}

Abstract: The processes of subsidence of nomads of the Central Asia in II c. b.c. - III c. a.d. are considered in article. Also the system of arrangement of balance of forces in the Kanguy state is investigated. Data on a problem of system of the government and political borders of Kanguy state are given. And as on the basis of sources social and economic, political development of the given state is studied. The reasons of disintegration of the Kanguy state are considered.

Key words: Fumu, Kanguy, nomadic, Dahya, agriculture, Guyshui, Hou Hanshu, Shi-ji, Dahya, Chach, Dayuan. Language: English

Citation: Biykuziev, A. A. (2019). Political and economic influence of the Kanguy confederation on the territory of the central Asian interfluve. ISJ Theoretical \& Applied Science, 05 (73), 575-578.

Soi: http://s-o-i.org/1.1/TAS-05-73-90 Doi: crossef https://dx.doi.org/10.15863/TAS.2019.05.73.90

\section{Introduction}

The ancient state of Kanguy, which was located in the territories of modern Uzbekistan and Kazakhstan, is mentioned in ancient Chinese written and historical chronicles as early as the 2nd century BC. The famous scientist I.Markvart relying on ancient written sources believed that Kanguy was "the state of the Saks of Chach" [1, P. 144]. The Han Empire tried to establish trade relations with Western countries and sent envoys through the territory of East Turkestan to Central Asia. The first ambassador and traveler who had to go through the possessions of Davani and Kanguy was Zhang Qiang. The emperor U-di sent him to conclude a treaty with the nomadic Yuezhi against the Hunnish Empire. Zhan Qian's journey lasted more than 12 years, but he failed to reach an agreement with Yue-chzhami. However, he managed to explore the territory of the Central Asian countries. Among them was named Kanguy, in whose rate the ambassador ruled was managed by the ambassador. By that time, at the turn of our era, the territory of Sogdiana was already dependent on the Kanguis nomads [2, P. 16-17].

\section{Materials and methods}

Therefore, possession of Kanguy began considerably to the south of the Aral Sea in the north, in the south reached the Big Yuechzhi occupying lands to the north from river of Guishui (Amu Darya River), and from the East for the West stretched along a caravan track from east coast of the Lake Issyk Kul approximately to the Tashkent region. Apparently, Kangyuy in the 1st century BC conquered a number of small kingdoms and expanded the possession what increase in number of its army (and according to the population) in comparison with the end of the $2 \mathrm{nd}$ century BC approximately on a third, from 80-90 thousand to 120 thousand people indirectly testifies to. On population (600 thousand) it became almost equal to Usun (630 thousand), surpassed Dawan (300 thousand) twice, but much more conceded to the Big Yuechzhi who took control of Dasya from it about 1.5 million people. In the description of Kanguy in "Han Shu" it is mentioned only his communications about Syunna what it is told also in "Shi Ji" about. However, in "Shi Ji" his close ties with Big Yuechzhi and Dawan to which he even helped with war against Han are noted. Most likely, their communications continued also in the 1st century BC, but in Han did not know about them [3, P. 184].

In the ancient Chinese sources, "The Narration of the Western Territory" and in the chronicle "Houhanshu", the state of Kanguy is described in more detail. Lifestyle was which still bound by the 


\begin{tabular}{|c|c|c|c|c|c|c|}
\hline \multirow{4}{*}{ Impact Factor: } & ISRA (India) & $=3.117$ & SIS (USA) & $=0.912$ & ICV (Poland) & $=6.630$ \\
\hline & ISI (Dubai, UAI & $=0.829$ & РИНЦ (Russia & $=0.156$ & PIF (India) & $=1.940$ \\
\hline & GIF (Australia) & $=0.564$ & ESJI (KZ) & $=8.716$ & IBI (India) & $=4.260$ \\
\hline & JIF & $=1.500$ & SJIF (Morocce & $=5.667$ & OAJI (USA) & $=0.350$ \\
\hline
\end{tabular}

nomadic traditions. According to sources, "the Kangui ruler has a stay in Loyueni's country in Bityan for 12,300 from Chanan [3, P. 184]. He does not depend on the governor. From Loyueni, seven days on the summer ruler's summer residence". That is, Kanguy had its sovereignty and was an independent state. The population of Kangyuya consisted of 120,000 families, 600,000 souls; troops 120,000 people [3, P. 184]. Kanguy was located between Davan (Fergana) in the southeast or south, Usuni (Semirerychye tribes) in the northeast, the Great Yue-chi in the west and Dahya (Bactria) in the south-west. Of course, the Kanguans, like other nomads, needed agricultural goods and sought to control the settled territories. In this case, it is the territory of the Zeravshan Valley, where were the main agricultural products for the steppe part of the state. From ancient Chinese sources, it is known that Kanguy, in $46-36$ years BC was able to support the northern Huns led by Zhizhi Shanyu. But after the Han governor in Eastern Turkestan, Gan Yen-sheu, and his assistant, Chen Than, gathered Chinese warriors and troops from the states of the Western Territory defeated Zhizhi Shanyu, Kanguy began a very careful foreign policy against China [3, P. 184].

The Kangyu confederation owned the lands of almost the entire Sogdiana. These are the territories of Susye (Shahrisabz), Fumu (Kattakurgan district), Yuni (Tashkent region), Guy (Bukhara valley), and Yugyan (Urgench region) [4, P. 118]. The cultural influence on Sogdiyana from the territory of Northern Bactria was not always even dimensional. Bactria (Dahya or Dasia) which was finally conquered by the big Yue-chi in the years 100-99 BC began to assign the local and Greek forms of government [5, P. 127]. The ceramics of the Hellenistic Bactria reached only the southernmost parts of the Zeravshan Valley, but did not spread further due to the political influence of the nomadic Kangyuichevs. All the ceramics of the Extreme Saverna Bactria were made on a potter's wheel, firing of high quality, but not always uniform [6, P. 44] Rival Kanguya in Sogdiana certainly was the Kushan Empire. Trade transit through the lands of the Zeravshan Valley has always been under the watchful attention of both states. Possessing political power in Sogdiyan, the Kanguis tried to establish a unitary control over the given territory. The Kushans, on their part, looked at Sogdiana as a buffer zone between Kanguy. As a result, the borders of Northern Bactria depended on the political situation between Kanguy and the Kushan Empire. Kanguy also had a mutual border with Anxi (Parthia) in the south with which he led an active trade passing Chinese goods through its territory [3, P. 182].

In ancient Chinese sources, it is also reported that "Kanguy, on the contrary, is proud and bold and in no way agrees to do worship in front of our messengers. Officials sent to him from the governor, plant below Usun ambassadors. Princes and foremen are served food before, and then sent from the governor. "This we can conclude that the Kanguis understood very well the distance of Kataya from their own country and led a free foreign policy in Central Asia.

The foreign policy of the Kanguy state throughout its entire existence was the desire to keep under its control a section of the Silk Road from Sogdiana, Fergana and to the Aral Sea region, which was held along the Syrdarya. This was especially connected with the Roman Eastern trade. In which the leading role belonged to the Alexandrian merchants whose goods passed through the lands of the Kushan Empire and Kanguy. And then this trade spread to the Han Empire. Trade routes were of strategic importance because ambassadors of foreign countries moved along them [7, P. 79].

Nomadic Kangyu settlements are usually surrounded by burial grounds, of which ZhamanTogai, Torebay-Tumsyk and others were excavated. Burials were carried out in the catacombs with a dromos perpendicular to their long axis. The graves were paired single burial of one, two or more vessels, beads, iron buckles. Archaeological findings prove that the population of Kangyu long kept the nomadic traditions of the ancient Saks. Kangyuy owning Chachsky oasis and Zeravshan valley, provided the nomadic aristocracy with agricultural goods. The main core of the power of the nomadic population of Kangyui Saki was in equal rights with the sedentary inhabitants of this state. However, the political elite adhered to the nomadic traditions of their ancestors. However, the religion of the Sogdians began to influence the nomadic tribes of Kangyui and part of them accepted the teachings of Zarathushtra. What was the early faith of the Pre-zoroastrian Sakas remains the subject of controversy among scientists. Probably they were culturally very brilliant towards Zoroastrianism, because the population of Kanguy perceived it rather quickly. However, whether Zoroastrianism was the state religion has not yet been proven.

The economy of the Kanguis gradually developed on the basis of sedentarization, the craft, agriculture began to prevail in the middle course of the Syrdarya due to the influence of the Zeravshan agricultural oases. The ancient Kanguyans, like the Sogdians, kept their products in large ceramic vessels (humah), which they dug into the ground indoors. They knew the secret of smelting iron; they made labor tools and household goods from them. They also made knives, arrowheads, etc. from iron. The cultivation of land for irrigated farming in the state of Kanguy was carried out mainly with stone hoes, which shows the considerable backwardness of some territories of this state. In the agricultural regions of the middle course of the Syrdarya, bone tools were also used. In the economy Kanguy cattle for a long time played a major role in the lives of local residents. 


\begin{tabular}{|c|c|c|c|c|c|c|}
\hline \multirow{4}{*}{ Impact Factor: } & ISRA (India) & $=3.117$ & SIS (USA) & $=0.912$ & ICV (Poland) & $=6.630$ \\
\hline & ISI (Dubai, UAI & $=0.829$ & РИНЦ (Russia & $=0.156$ & PIF (India) & $=1.940$ \\
\hline & GIF (Australia) & $=0.564$ & ESJI (KZ) & $=8.716$ & IBI (India) & $=4.260$ \\
\hline & JIF & $=1.500$ & SJIF (Morocco & $=5.667$ & OAJI (USA) & $=0.350$ \\
\hline
\end{tabular}

Many Kanguans for a long time continued to engage in nomadic and grazing livestock.

In the first century $\mathrm{AD}$ in the main territory of Kanguy, irrigation was of limited size. The agricultural population of Chach, which was an integral part of Kangyu, used the waters of the Syrdarya using simple techniques. That is, ducts were dumbed out of which the canals were brought, which brought water to the fields of the farmers.

The Kanguans also practiced hunting. During archaeological excavations, the remains of saiga bones, argali, roe deer and others were found. Kanguians hunted geese, ducks and other waterfowl birds of the Syrdarya. Fishing was developed which involved farmers and nomads in the state. The fruits were mainly supplied from Sogdiana and neighboring Davan.

The political weakening of Kanguy begins simultaneously with the collapse of the Kushan Empire in the south. Chinese sources report that 270 $\mathrm{AD}$ the last embassy was sent to China. The sources have evidence that later began the period of the collapse of the Kangui confederation into a large number of possessions, each of which had an independent ruler, but they all considered themselves descent of Kanguy confederation held an advantageous geographical location at the end of antiquity period. Through its lands the transit road of the Great Silk way ran. The coins found by archeologists in the territory of Uzbekistan and the South of Kazakhstan suggest the development of trade. Archeologists dated time of stamping of coins of the 3th-4th centuries AD.

Kanguy (or Saky) lived on the busiest site of the Great Silk way. They controlled that its site which went on the Caucasus and to Black Sea Coast. The geopolitical status of this state was always we mean during the antique period So-so the Asian region.

Transition to nomadic cattle breeding meant large economic progress in life of tribes of steppes and deserts. Economic development of extensive spaces was promoted by the horse breeding growth, which received especially broad scope at the beginning of the first millennium BC. Use of a stepnyakama of a saddle horse, emergence of a cavalry destroyed cultural and economic isolation of certain areas, provided a wide economic and cultural communication with neighbors and certain tribes, the people and the states dants of the Yue-Chzh nobility [8, P. 400].
At comparative characteristic of regions of Central Asia eras of Kangyuya the uniform cultural and economic zone from lower reaches of the Syr Darya to Fergana is allocated. The agricultural and cattle breeding economy, monumental architecture and fortification, the small strengthened settlements as the leading type of resettlement, limitation of monetary circulation are characteristic of it.

It is obvious that the location of Kanguy to the North West from Dawan did not change, but the capital instead of Bitian called Sousse, "Han Shu" who was in the 1st century BC, by data, by the capital of possession, dependent on Kanguy. And kingdoms Yan and Il (perhaps, so began to be called Sui), as well as Yancai which is not mentioned at all, did not submit to it any more, i.e. the sign of falling of former power of Kanguy to III-of the 4th centuries AD is available. Moreover, the instruction that at that time kangyuys on shape, customs and clothes were similar to davanyets is especially interesting in this description. Dawanci, according to the message in "Shi Ji" repeated in "Han Shu" were Caucasians, led a settled life and were engaged in agriculture [2, P. 44-45].

It turns out, as kangyuyets were Caucasians that in the II-I centuries BC they were nomads, and by 4th century $\mathrm{AD}$ passed to a settled way of life, but, judging by the description, were engaged in distantpasture cattle breeding. However, this question remains debatable among the famous scientists as Y.F. Buryakov, R.H. Suleymanov, A.N.Podushkin and etc. In the 3th-4th centuries Kanguy loses the hegemony over possession in Central Asian Entre Rios.

\section{Conclusion}

Thus, by the end of the III century Kanguy disintegrated into several independent states due to internal political factors. The first to leave the state of Yancay (Khorezm) is a territory dependent on Kanguy. The rest of the possessions of Kanguy Chach and Sogd Pozhe became independent. In spite of this, the former possessions of the Kanguyas maintained political, economic, and cultural ties with China, Iran, and the Roman Empire.

In the 5th century, it is known in the list of the countries, which sent embassy to China probably, by this time the small possession, which arose on the place Kanguy become dependent on the Eftalits state.

References:

1 Markwart, J. (1938). Wehrot und Arang. (p.188).

Leiden. 


\begin{tabular}{|c|c|c|c|c|c|c|}
\hline \multirow{4}{*}{ Impact Factor: } & ISRA (India) & $=3.117$ & SIS (USA) & $=0.912$ & ICV (Poland) & $=6.630$ \\
\hline & ISI (Dubai, UAE & $=0.829$ & РИНЦ (Russia & $=0.156$ & PIF (India) & $=1.940$ \\
\hline & GIF (Australia) & $=0.564$ & ESJI (KZ) & $=8.716$ & IBI (India) & $=4.260$ \\
\hline & JIF & $=1.500$ & SJIF (Morocce & $=5.667$ & OAJI (USA) & $=0.350$ \\
\hline
\end{tabular}

2 (1932). Geography of Claudius Ptolemy. Transl. into English and ed. by E. J. Stevenson (Eds.). (p.144). New York.

3 Litvinskiy, B. A. (1968). Kangyuyskosarmatskiy farn. ( $k$ istoriko-kul'turnym svyazyam plemen yuzhnoy Rossii i Sredney Azii). (pp.1617). Dushanbe. 1968.

4 Bichurin, I. Y. (1950). Sobranie svedeniy o narodakh, obitavshikh $v$ Sredney Azii v drevnie vremena. II tom. (p.184). Moscow.

5 Shoniezov, K. (2001). Uzbek khalķining shakllanish zharaeni. (p.118). Tashkent.
6 Borovkova, L. A. (2005). Kushanskoe tsarstvo po drevnim kitayskim istochnikam. (p.127). Moscow.

7 Mandel'shtam, A. M. (1975). Pamyatniki kochevnikov kushanskogo vremeni v Severnoy Baktrii. (p.44). Leningrad.

8 Litvinskiy, B. A. (1986). Vostochnyy Turkestan $i$ Srednyaya Aziya v sisteme kul'tur drevnego $i$ srednevekovogo Vostoka. (p.79). Moscow.

9 Mc. Govern, W. M. (1939). The early emperies of Central Asia. (p.400). New York. 